\title{
Comparison between two insecticide application methods in controlling lesser mealworm beetles in commercial broiler houses
}

\author{
Comparação de dois métodos de aplicação de inseticida no controle de cascudinho em aviários \\ comerciais
}

\section{Andrea Panzardi ${ }^{1}$, Rogério de Faria Nunes ${ }^{1}$, Thais Schwarz Gaggini ${ }^{1,2 \star}$, Gustavo Bomfim Alves de Oliveira $^{1}$, Ednaldo Carvalho Guimarães ${ }^{2}$, Robson Carlos Antunes ${ }^{2}$, Amilton Silva ${ }^{1}$ e Marcus Luciano Guimarães Rezende ${ }^{1}$}

${ }^{1}$ Ourofino Saúde Animal, Cravinhos, São Paulo, Brasil.

²Universidade Federal de Uberlândia, Uberlândia, Minas Gerais, *Autor para correspondência: tsgaggini@yahoo.com.br.

\begin{abstract}
The lesser mealworm control is mostly made by insecticides, as the association of chlorpyrifos, cypermethrin and citronellal. The traditional insecticide application method (TRADM) depends on many liters of water and, with the objective of reducing water consumption, the aim was to compare TRADM with atomizer-equipment method (ATOMM). Four and three houses from farm A and B were used, respectively. Houses 1,3 and 7 were treated with TRADM ( 1 liter of insecticide diluted in 500 liters of water) and houses 2, 4, 5 and 6 with ATOMM ( 1 liter of insecticide diluted in 9 liters of water). Twenty-four hours before and 30 (for farm A) and 45 days (for farm B) after the insecticide application, the number of insects was counted in each house (using 18 mapped traps/house). Farms were not considered different $(p>0.05)$ and comparison was made between the houses. Houses were different $(p<0.001)$ in the pre-treatment count, but they were equal in the second count $(\mathrm{p}=0.97)$. The insecticide application increased the number of traps without any insect $(p<0.0001)$. In conclusion, the application method of chlorpyrifos, cypermethrin, and citronellal insecticide using atomizer equipment presented similar results than using the traditional application method. Both methods were effective in reducing the infestation of all houses, not making any difference if the dilution of the product was in 500 liters or in 9 liters of water; thus, it is possible to spend less water to run this management.
\end{abstract}

KEYWORDS: Alphitobius diaperinus, atomizer, insect control, poultry.

\section{RESUMO}

O controle do cascudinho é realizado principalmente por inseticidas, como a associação entre clorpirifos, cipermetrina e citronelal. O método tradicional de aplicação do inseticida (TRADM) depende de grande volume de água para a diluição e, visando à redução do uso de água, o estudo objetivou comparar TRADM com o método utilizando atomizador (ATOMM). Quatro galpões da propriedade A e três da B foram utilizados. Os galpões 1, 3 e 7 foram tratados com TRADM ( 1 litro inseticida:500 litros de água) e os galpões 2, 4, 5 e 6 tratados utilizando ATOMM (1 litro de inseticida:9 litros de água). Vinte e quatro horas antes e 30 (para A) e 45 dias (para B) após a aplicação foi realizada a contagem de cascudinhos em cada galpão (18 iscas mapeadas/galpão). Não houve diferença $(p>0,05)$ entre as propriedades e os galpões foram considerados nas comparações. Estes diferiram quanto à contagem pré-tratamento $(p<0,001)$, mas não diferiram na contagem pós-tratamento $(p=0,97)$. A aplicação do inseticida aumentou o número de iscas sem insetos $(p<0,0001)$. Concluindo, a aplicação do inseticida a base de clorpirifos, cipermetrina e citronelal usando atomizador apresentou resultado semelhante ao do método tradicional. Ambos os métodos são efetivos para reduzir a infestação de todos os galpões, não fazendo diferença se a diluição do produto foi realizada em 500 ou 9 litros de água; dessa forma, é possível gastar menor quantidade de água para realizar esse manejo.

PALAVRAS-CHAVE: Alphitobius diaperinus, atomizador, avicultura, controle de insetos.

The lesser mealworm (Alphitobius diaperinus (Panzer) (Coleoptera:Tenebrionidae)) was primarily known as a secondary pest of flours, food and stored grain by-products (REZENDE et al. 2009) but 
nowadays it is fully adapted to broiler houses and it is considered one of the major problem in world poultry production (AXTELL 1994). The current farm systems and broiler management facilitate the proliferation of this plague in the middle of feces, food, and, mostly in broiler litter (AXTELL \& ARENDS 1990).

The presence of the insect in poultry production promotes behavioral changes in broilers, such as scratching. Also, the lesser mealworm can be consumed, promoting injuries in the carcass, causing an indirect and negative effect on broiler feed intake and feed conversion (REZENDE et al. 2009). When there is consumption, the insect can cause toxicity, may cause liver lesions and condemn the carcass (TSENG et al. 1971) and it can also act as a mechanical host for pathogenic microorganisms responsible for transmitting diseases to broilers (DESPINS et al. 1994, DESPINS \& AXTELL 1995, MCALLISTER et al. 1995, SILVA et al. 2006, LEFFER et al. 2010, MORAES et al. 2014).

Lesser mealworm control is important to manage in order to increase and qualify the production since the insect has great ability to survive in periods between batches and to reinfest after the broiler housing. The insect population control is mostly made by chemical insecticides (GAZONI et al. 2012), as the association of chlorpyrifos, cypermethrin, and citronellal. This product has already shown to be an interesting alternative to control larvae and adults (WOLF et al. 2015) of lesser mealworm being clinically safe and without presenting residues in the meat (SILVA et al. 2001).

The traditional application method of the chlorpyrifos, cypermethrin, and citronellal insecticide is based on its dilution in many liters of water. In order to check the possibility to use less water and still obtain the same results related to lesser mealworm infestation, the aim of this study was to compare the traditional insecticide application method with a new application method, using atomizer equipment.

This research was performed in naturally infested broiler houses located in Parana State, Brazil, from June to July 2015. The study was conducted in two different farms ( $A$ and $B$ ). Four broiler houses were used in farm $A$ and three in farm B. All houses had $150 \times 16$ meters of area, metal roof, dirty floor, side curtains and the same conditions of production. Wood-shavings litter of the $A$ and $B$ farms had been used 11 and 6 times, respectively.

Before the insecticide application and with broilers inside the houses, the number of $A$. diaperinus was counted in each house of both systems using the methodology based in SAFRIT \& AXTELL (1984) and in a method of modified traps of Arends' researches (SILVA et al. 2001). Forty-eight hours before the insecticide application, 18 trap (PVC tubes with $50 \mathrm{~mm}$ of diameter and $15 \mathrm{~cm}$ of length) were buried under the broiler litter and were distributed according to this pattern: six traps next to the wall and twelve traps next to the feeders. After 24 hours, the content of each trap was placed in a bowl and the number of A. diaperinus was counted (pre-treatment count).

Broilers were removed from their houses one day before the insecticide treatment. The chlorpyrifos, cypermethrin, and citronellal insecticide used in the study is a commercial product with concentration of $15 \%$, $25 \%$ and $1 \%$, respectively. In farm $A$, insecticide was applied using the traditional method (TRADM) in houses 1 and 3 , and using the atomizer equipment method (ATOMM) in houses 2 and 4 . In farm B, insecticide was applied using TRADM in house 7 and using ATOM in houses 5 and 6.

It was used 1 liter of insecticide for each $1200 \mathrm{~m} 2$ of the area, diluted in 500 liters of water for TRADM. The insecticide application was made in closed curtains and with the ventilation systems off. A wash pump attached to a hose nozzle was used to apply insecticide in farm A, and a hose attached to a spray tank linked to a tractor in farm B. After the insecticide application, broiler litters were covered with canvas for 48 hours, and during this period the curtains were kept closed. For the ATOMM it was used 1 liter of insecticide for each $1200 \mathrm{~m} 2$ of the area, diluted in 9 liters of water. For farms A and B it was used a costal atomizer (Kawashima, KWS 8020) with an adapter for liquid with a maximum flow rate of 2 liters per minute. After the insecticide application, broiler litters were covered with canvas for 48 hours, and during this period the curtains were kept closed.

After 30 days for farm $A$ and 45 days for farm B, the number of $A$. diaperinus was recounted (posttreatment count) following the same methodology used at the pre-treatment count. All data collected were statistically analyzed considering the difference between farms, differences between houses and differences between insecticide application methods. Anderson-Darling test was performed to test the normality of the distribution of the variables and plots were made to check normality of residuals. The number of $A$. diaperinus in the pre-treatment count, in post-treatment and the difference between pre-treatment and posttreatment count (DIFF-PRE-POST) was considered non normal $(p<0.05)$ and due to this information all variables were evaluated with Kruskal-Wallis test to compare houses and with Mann-Whitney test to compare farms. McNemar test was done to compare the proportion of $A$. diaperinus before and after the treatment, considering how many traps had zero A. diaperinus counted in both situations. All the analysis 
was done using Software R (R DEVELOPMENT CORE TEAM 2011).

There was no difference between farms $A$ and $B$ for pre-treatment count $(p=0.23)$, post-treatment count $(p=0.65)$ and DIFF-PRE-POST $(p=0.96)$. Due to this result, comparison between houses was made considering farms $A$ and $B$ as equal.

There was difference between treatments in the pre-treatment count $(p<0.001)-($ Table 1$)$. These differences in the pre-treatment count could be related to variation in the health challenge of each house, which usually occurs in animal production systems. In this case, houses with a higher number of $A$. diaperinus probably had more micro-environments with adequate temperature, humidity, and presence of shelter and food (SALIN et al. 2000) for insect survival than houses with less infestation.

Table 1. Pre-treatment count of Alphitobius diaperinus (before insecticide application), post-treatment count of $A$. diaperinus (after insecticide application) and difference between pre-treatment and posttreatment count using two different methodology of insecticide application.

\begin{tabular}{llll}
\hline Houses & $\begin{array}{l}\text { Pre-treatment count of } \\
\text { A. diaperinus }\end{array}$ & $\begin{array}{l}\text { Post-treatment count of } \\
\text { A. diaperinus }\end{array}$ & $\begin{array}{l}\text { Difference between } \\
\text { 1st and 2nd count }\end{array}$ \\
\hline ATOMM2A & $0 ; 11 ; 78(17.94) \mathrm{a}$ & $0 ; 0 ; 69(6.89)$ & $-56 ;-6 ; 1(-11.06) \mathrm{ac}$ \\
ATOMM4A & $0 ; 2 ; 31(5.05) \mathrm{ac}$ & $0 ; 0 ; 35(4.11)$ & $-15 ;-1 ; 17(-0.94) \mathrm{bc}$ \\
ATOMM5B & $0 ; 1 ; 29(3.67) \mathrm{bc}$ & $0 ; 0 ; 21(3.00)$ & $-16 ; 0 ; 15(-0.67) \mathrm{b}$ \\
ATOMM6B & $1 ; 11 ; 40(13.83) \mathrm{ac}$ & $0 ; 0 ; 13(2.06)$ & $-38 ;-9 ; 1(-11.78) \mathrm{a}$ \\
TRADM1A & $0 ; 9 ; 86(15.06) \mathrm{ac}$ & $0 ; 0 ; 39(6.2)$ & $-71 ;-4 ; 27(-8.83) \mathrm{ab}$ \\
TRADM3A & $0 ; 5 ; 49(10.39) \mathrm{ac}$ & $0 ; 0 ; 44(6.55)$ & $-25 ;-2 ; 16(-3.83) \mathrm{ab}$ \\
TRADM7B & $0 ; 3 ; 79(11.28) \mathrm{ac}$ & $0 ; 0 ; 15(2.94)$ & $-64 ;-3 ; 0(-8.33) \mathrm{ab}$ \\
\hline
\end{tabular}

$\bar{a}, \mathrm{~b}, \mathrm{c}$ indicate statistical difference among groups $(\mathrm{p}<0.001)$, using Kruskal-Wallis test.

Values presented as minimum; median; maximum (mean).

The number after ATOMM and TRADM indicates the house and the letter $A$ and $B$ indicates the farm where the treatment was done. ATOMM = houses where were used the atomizer equipment method to apply chlorpyrifos, cypermethrin and, citronellal insecticide. TRADM = houses where were used the traditional method to apply chlorpyrifos, cypermethrin, and citronellal insecticide.

The DIFF-PRE-POST did not differ between houses and between the methodology of insecticide application ( $p=0.97$ ). Median of all results for the DIFF-PRE-POST was zero or a negative number. Considering this difference, houses with a higher infestation in the pre-treatment count presented higher DIFF-PRE-POST too $(p<0.001)$. These results indicate that the utilization of insecticide containing chlorpyrifos, cypermethrin, and citronellal, independently of the application method and the quantity of water necessary to apply the product, proved to be a good way to reduce the number of lesser mealworm in houses with different infestation degrees.

For our knowledge, there is no similar research published in the literature. Studies about lesser mealworm control take into account the protocol and the insecticide used, but not the amount of water required for its application. For this reason, the discussion will be based on published results that used different protocols.

Although SILVA et al. (2007) observed 100\% of effectiveness rate for chlorpyrifos, cypermethrin, and citronellal insecticide in the laboratory against $A$. diaperinus larvae and adults, to obtain $100 \%$ of effectiveness rate in field routine is not so simple due to the complexity of controlling $A$. diaperinus (CHERNAKI-LEFFER et al. 2007, WOLF et al. 2015). Only the use of chemical products is not enough to control the insect infestation, and the answer could be variable, heavily depending on environmental characteristics of the house (CHERNAKI-LEFFER et al. 2007). As WOLF et al. (2015) have shown the combination of control methods including insecticide application and environmental management is desirable to achieve high effectiveness rate against the insect.

From 126 traps analyzed, only two traps (1.59\%) presented no insect before and at least one insect after the insecticide application, and 60 traps $(47.62 \%)$ presented at least one insect before and no insect after insecticide application ( $p<0.0001$, using McNemar test). Previous studies did not mention which is the infection threshold when the number of $A$. diaperinus is counted, but in theory, the insecticide application should be recommended when the insect level becomes an economic problem (AXTELL \& ARENDS 1990). In practice it is not possible to wait because to avoid the insecticide application means that the lesser mealworm could spread to other houses and farms, increasing the problem. In field routine, the insecticide 
application is indicated after the detection of a single parasite through monitoring programs (AXTELL \& ARENDS 1990). In the present case, chlorpyrifos, cypermethrin, and citronellal insecticide application promoted an increase in the number of traps without any A. diaperinus, contributing to biosecurity practices and avoiding the risk of transporting the insect from one house to another.

In conclusion, the application method of chlorpyrifos, cypermethrin, and citronellal insecticide using atomizer equipment presented similar results than using the traditional application method. Both methods were effective in reducing the infestation in all houses, not making any difference if the dilution of the product was in 500 liters or in 9 liters of water; thus, it is possible to spend less water to run this management.

\section{REFERENCES}

AXTELL RC. 1994. Biology and economic importance of the darkling beetle in poultry houses. In: Proceedings of the North Carolina State University Poultry Supervisors' Short Course. p. 8-17.

AXTELL RC \& ARENDS JJ. 1990. Ecology and management of arthropod pests of poultry. The Annual Review of Entomology 35: 101-126.

CHERNAKI-LEFFER AM et al. 2007. Populational fluctuation and spatial distribution of Alphitobius diaperinus (Panzer) (Coleoptera; Tenebrionidae) in a poultry house, Cascavel, Paraná State, Brazil. Brazilian Journal of Biology 67: 209213.

DESPINS JL \& AXTELL RC. 1995. Feeding behavior and growth of broiler chicks fed larvae of the darkling beetle, Alphitobius diaperinus. Poultry Science 74: 331-336.

DESPINS JL et al. 1994. Transmission of enteric pathogens of turkeys by darkling beetle larva (Alphitobius diaperinus). Journal of Applied Poultry Research 3: 61-65.

GAZONI FL et al. 2012. Evaluation of Beauveria bassiana (986) as a Biological Control of Alphitobius diaperinus in Poultry Broiler litter of Wood Shavings. Acta Scientiae Veterinariae 40:1016.

LEFFER AM et al. 2010. Vectorial competence of larvae and adults of Alphitobius diaperinus in the transmission of Salmonella Enteritidis in poultry. Vector-Borne and Zoonotic Diseases 10: 481-487.

MCALLISTER JC et al. 1995. Isolation of Bursal Disease virus from the lesser mealworm, Alphitobius diaperinus (Panzer). Poultry Science 74: 45-49.

MORAES DMC et al. 2014. Fontes de infecção e perfil de susceptibilidade aos antimicrobianos de Salmonella sp. isoladas no fluxo de produção de frangos de corte. Arquivos do Instituto Biológico 81: 195-201.

R DEVELOPMENT CORE TEAM. 2011. R: A language and environment for statistical computing R Foundation for Statistical Computing, Vienna, Austria ISBN 3-900051-07-0. URL: https://www.r-project.org/.

REZENDE SRF et al. 2009. Control of the Alphitobius diaperinus (Panzer) (Coleoptera: Tenebrionidae) with entomopathogenic fungi. Brazilian Journal of Poultry Science 11: 121-127.

SALIN C et al. 2000. Spatial distribution of Alphitobius diaperinus (Panzer) (Coleoptera: Tenebrionidae) in the soil of a poultry house along a breeding cycle. European Journal of Soil Biology 36: 107-115.

SAFRIT RD \& AXTELL RC. 1984. Evaluations of sampling methods for darkling beetles (Alphitobius diaperinus) in the litter of turkey and broiler houses. Poultry Science 63: 2368-2375.

SILVA AS et al. 2006. Ação do fungo Beauveria bassiana, isolado 986, sobre o ciclo biológico do cascudinho Alphitobius diaperinus em laboratório. Ciência Rural 36: 1944-1947.

SILVA GS et al. 2007. Effectiveness of the compound chlorpyrifos+cypermethrin+citronellal against Alphitobius diaperinus: Laboratory analysis and residue determination in carcasses. Brazilian Journal of Poultry Science 9: 157160.

SILVA GS et al. 2001. Avaliação de métodos de amostragem de "Cascudinhos" Alphitobius diaperinus (Panzer) (Coleoptera:Tenebrionidae) em cama de frangos de corte. Semina 22: 73-76.

TSENG YL et al. 1971. Morphology and chemistry of the odorifroos gland of the lesser mealworm, $A$ diaperinus (Coleoptera: Tenebrionidae). Annals Entomology of Society American 64: 425-430.

WOLF $\mathrm{J}$ et al. 2015. Combined physical and chemical methods to control lesser mealworm beetles under laboratory conditions. Poultry Science 94: 1145-1149. 